\title{
永久気管孔造設後の腕頭動脈破裂の成因と対策
}

\author{
平田行宏
}

\section{An Analysis of Innomunate Artery Rupture after Total Laryngectomy and Its Prevention}

\author{
Yukihiro Hirata, M.D. \\ Department of Otolaryngology, Kyoto Prefectural University of Medicine, Kyoto
}

\begin{abstract}
Life-threatning bleeding from the innominate artery is sometimes observed as a complication after total laryngectomy. Circulatory insufficiency with the use of a cuff enhances the necrotic process of the tracheal wall, and the tip of the tracheal cannula may provoke pressure necrosis on the anterior wall of the trachea and progressively injure the innominate artery. This hazardous complication is possible, if an improperly shaped cannula is used. The flexion of the tracheal cannulae available as commercial products can not match the trachea after total laryngectomy, because the trachea goes actually almost straight down to the carina, showing only a very slight curvature, this is clearly demonstrated in the MRI of laryngectomized patients. For the prevention of this complication, a new tracheal cannula has been developed, that is almost straight and matches the trachea of laryngectomized patients.
\end{abstract}

Key words : 永久気管孔, 腕頭動脈破裂, 不適合カニューレ

\section{I 、はじめに}

喉頭全摘に際しての永久気管孔造設後におけ る最も致命的な合併症の一つとして, 腕頭動脈 破裂による大出血がある。カフ圧による循環不 全に起因する気管壁の脆弱化も大きな要因とな るが，直接の原因は気管カニューレ先端部分で 気管前壁を圧迫することによる気管壁壊死と, そこから波及する感染壊死による腕頭動脈破裂

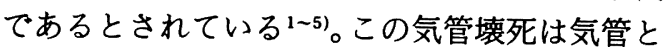
気管カニューレとの彎曲度の半径（以後 $R$ と呼 ぶことにする）の不適合によって生じると考え られているが，それを客観的に証明した報告は ない。そこで, 永久気管孔造設後の気管につい て, その形状特に $R$ および周囲組織との位置関

京都府立医科大学耳鼻咽喉科学教室

別刷請求： 个570-8540 守口市外島町5-55 松下記念病院耳鼻咽喉科 平田行宏

投稿受付：1998年 7 月29日（急載）
係について MRI を用いて検討し，現在広く臨 床で用いられている気管カニューレの形状, 特 にその $R$ との不適合について明らかにし，気管 壁壊死と腕頭動脈破裂の成因について検討し た。また，その予防を目的として，適切な $R$ を もつ気管カニューレを試作した。

\section{II. 対 象}

1989年より1997年までの間に，京都府立医科 大学耳鼻咽喉科において永久気管孔を造設後再 発なく生存している患者の中で, MRIによる検 査に合意を得た 22 症例を対象とした。その内訳 は, 喉頭癌で単純喉頭摘出した13症例, 下咽頭 癌（頸部食道癌）で喉頭下咽頭頸部食道を摘出 し遊離空腸を用いて再建した 3 症例，喉頭下咽 頭食道を全摘出し胃または大腸を用いて再建し た 4 症例, 甲状腺癌で気道浸潤のため胸骨上縁 で気管を切断し, 胸骨柄を切除して縦隔気管孔 を造設した 2 症例である。なお単純喉頭摘出を 
表 1 症例一覧

\begin{tabular}{|c|c|c|c|c|c|}
\hline 症例 & 年齢 & 性別 & 疾患 & 術 式 & $\begin{array}{c}\text { 気管切断レベル } \\
\text { (数字は気管リングを示す) }\end{array}$ \\
\hline 1 & 72 & 男 & $\mathrm{L}$ & 喉摘 & $2-3$ \\
\hline 2 & 69 & 男 & $\mathrm{L}$ & 喉摘 & $4-5$ \\
\hline 3 & 56 & 男 & $\mathrm{L}$ & 喉摘 & $2-3$ \\
\hline 4 & 63 & 男 & $\mathrm{H}$ & 空腸再建 & $4-5$ \\
\hline 5 & 70 & 男 & $\mathrm{L}$ & 喉摘 & $4-5$ \\
\hline 6 & 65 & 男 & $\mathrm{H}$ & 結腸再建 & $4-5$ \\
\hline 7 & 82 & 男 & $\mathrm{L}$ & 喉摘 & $5-6$ \\
\hline 8 & 81 & 男 & $\mathrm{L}$ & 喉摘 & $4-5$ \\
\hline 9 & 72 & 女 & $\mathrm{H}$ & 胃管再建 & $4-5$ \\
\hline 10 & 71 & 男 & $\mathrm{H}$ & 胃管再建 & $4-5$ \\
\hline 11 & 69 & 男 & $\mathrm{H}$ & 胃管再建 & $4-5$ \\
\hline 12 & 52 & 女 & $\mathrm{L}$ & 喉摘 & $2-3$ \\
\hline 13 & 60 & 男 & $\mathrm{L}$ & 喉摘 & $4-5$ \\
\hline 14 & 56 & 男 & $\mathrm{L}$ & 喉摘 & $4-5$ \\
\hline 15 & 65 & 男 & $\mathrm{L}$ & 喉摘 & $5-6$ \\
\hline 16 & 54 & 女 & $\mathrm{L}$ & 喉摘 & $2-3$ \\
\hline 17 & 62 & 男 & $\mathrm{L}$ & 喉摘 & $5-6$ \\
\hline 18 & 65 & 男 & $\mathrm{L}$ & 喉摘 & $4-5$ \\
\hline 19 & 62 & 男 & $\mathrm{T}$ & 縦隔気管孔 & $6-7$ \\
\hline 20 & 58 & 男 & $\mathrm{H}$ & 空腸再建 & $4-5$ \\
\hline 21 & 63 & 女 & $\mathrm{T}$ & 縦隔気管孔 & $6-7$ \\
\hline 22 & 59 & 男 & $\mathrm{H}$ & 空腸再建 & $4-5$ \\
\hline
\end{tabular}

喉頭癌を $\mathrm{L}$, 下咽頭癌を $\mathrm{H}$, 甲状腺癌を $\mathrm{T}$ とする。

施行した13症例の気管切断レベルは, 喉頭癌の 下方進展の程度によって決定されたが，2-3 リング間が 4 症例, $4-5$ リング間が 6 症例, $5-6$ リング間が 3 症例で, これらの症例では すへて緊張のない位置で頸部に永久気管孔が造 設された。また下咽頭癌では全例 $4-5$ リング 間で切断され，すくなくとも一側で頸部郭清術 が施行された。性別は男性18症例, 女性 4 症例 で, 年齢は52歳から82歳であった。おのおのの 症例については表 1 にまとめた。

\section{III. 方 法}

\section{MRI の撮影方法}

仰臥位で，正常頭位，頭部を前屈した場合お よび後屈した場合のそれぞれについて，気管孔 正中を含む $5 \mathrm{~mm}$ 間隔矢状断および前額断の MRI を撮影し, 得られた画像を生体と同一サイ スに調整した。

\section{2. 気管の形状とRの計測}

永久気管孔造設後の気管は気管孔からほほ直 線状に分岐部へ至る。一方, 臨床で一般に用い られている気管カニューレの形状は彎曲度の半 径 $R$ の円の 4 分の 1 円弧として設計されてい る6)。そこで両者のマッチングを検討するため に，以下の方法で気管の $R$ を計測した。

MRI 矢状断像を用い, 一般的な気管カニュー レの長さが成人用で約 $70 \mathrm{~mm}$ であることを考 慮し, 気管孔から $70 \mathrm{~mm}$ の範囲で計測すること にした。まず, 図 1 に示すように画像上気管孔 中央に点Aを設定し, 次に気管孔から $70 \mathrm{~mm}$ の 距離に点 $\mathrm{C}$ を設定した。つづいて点 $\mathrm{A} ・$ 点 $\mathrm{C}$ を

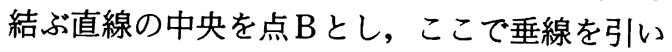

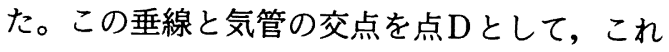
らがいずれも気管中央に位置するように設定し た。 $\mathrm{A}, \mathrm{D}, \mathrm{C} の 3$ 点を含む円弧を想定し, そ の半径を気管彎曲の半径 $R$ として $\mathrm{mm}$ で表し 
日気食会報，49（6）, 1998

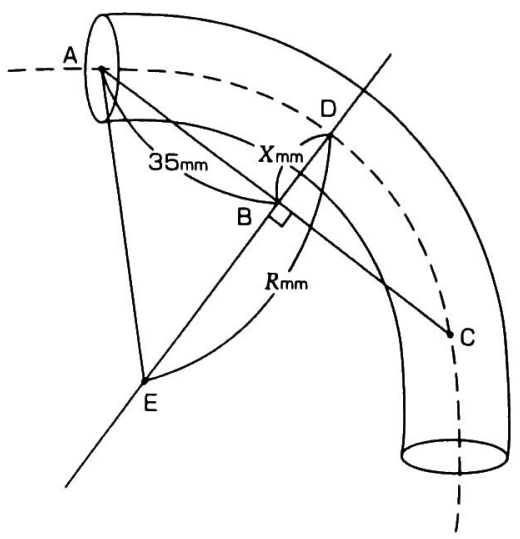

図 1 気管の $R$ の計測図

$\mathrm{AE}=\mathrm{DE}=\mathrm{CE}$ であり,$R^{2}=35^{2}+(R-x)^{2}$ が成立す る。よって $R=x / 2+1225 / 2 x$ となる。

た。すなわち点 $\mathrm{B}$ を通る直線上に $\mathrm{DE}=\mathrm{AB}(=$ $\mathrm{CE}$ )となるように点 $\mathrm{E}$ を設定すれば，この $\mathrm{DE}$ が $R$ となる。 $\mathrm{BD}$ の計測値を $x$ とすれば， $(R-$ $x)^{2}+35^{2}=R^{2}$ となり,$R=x / 2+1225 / 2 x$ とし て算出できる。

\section{3. 気管と周囲組織との位置関係}

$5 \mathrm{~mm}$ 間隔矢状断および前額断の MRI 画像 上で周囲の血管, とくに腕頭動脈の走行を検索 し, 気管との位置関係について観察した。また, 気管孔から腕頭動脈が最も気管に接する前壁ま での距離を計測した。

\section{IV. 結 果}

\section{1. 気管カニューレおよび気管のR}

臨床で広く用いられている数種類の成人用サ イズの気管カニューレの $R$ は最小 $30 \mathrm{~mm}$, 最大 $41 \mathrm{~mm}$, 平均 $36 \mathrm{~mm}$ であった。一方, MRI 画像 より測定した永久気管孔造設後の気管の $R$ の最 小值は $160 \mathrm{~mm}$, 最大值は $480 \mathrm{~mm}$ で, 平均值は $293 \mathrm{~mm}$ であった。例外的に $R$ が $91 \mathrm{~mm}$ という 症例が 1 例のみ存在した (図 $2,3,4$ )。気管 切断レベルと $R$ との関係については一定の規則 性は観察されなかった。また頭位による $R$ の変 化は認められず，性別との関係も認められなか つた。

\section{2 . 気管と周囲組織との位置関係}

図 5，6に示すMRI 画像によって明らかな ように, 永久気管孔造設後の気管前方には腕頭

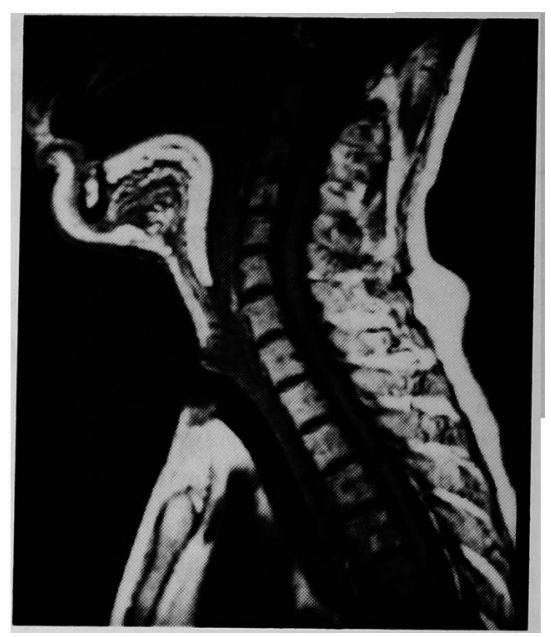

図 2 単純喉摘症例の MRI（Rは334 mm である）

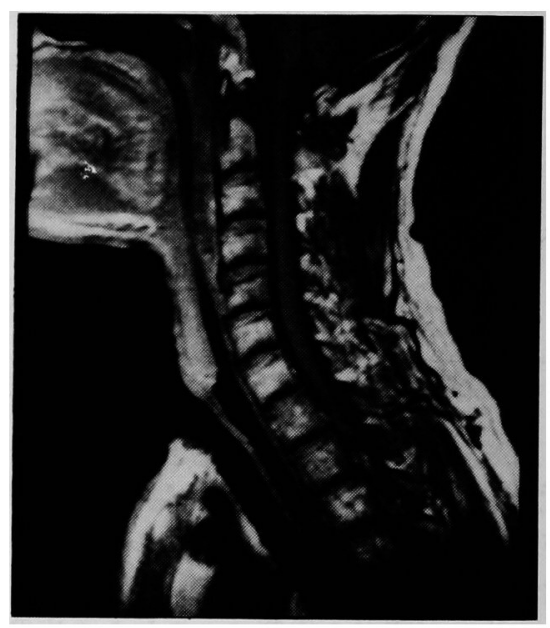

図 3 咽喉食摘空腸再建症例の MRI（ $R$ は348 mmである)

動脈がほほ接していて, 左下方から右上方へ斜 走し，その長さは約 3 リングに相当することが わかった。気管孔から腕頭動脈が最も気管に接 する前壁までの距離は, その症例の気管切断レ ベルと密接に関係があり, $2-3$ リング間で切 断したものの平均値は60 $\mathrm{mm}$ で, 一般的な長さ の気管カニューレの先端で損傷され得る距離で あった。 $4-5$ リング間で切断したものの平均 值は $50 \mathrm{~mm}, 6-7$ リング間で切断したものの 平均値は $40 \mathrm{~mm}$ であった。一方, 縦隔気管孔と したものでは気管孔直下に存在していた。 


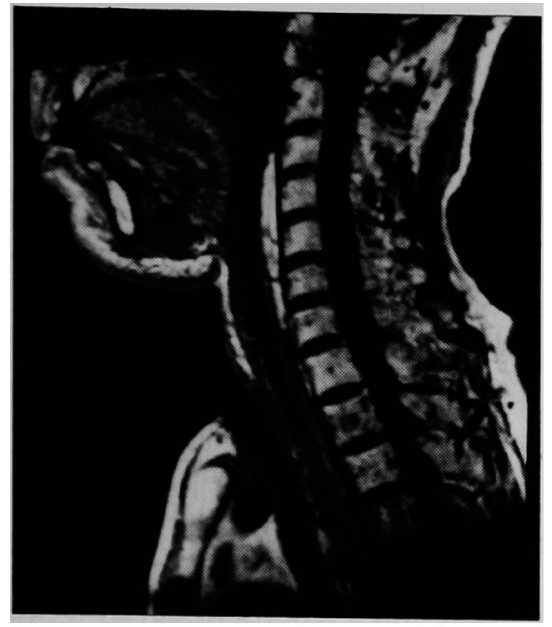

図 4 咽喉食摘結腸再建症例の MRI（ $R$ は338 mm である)

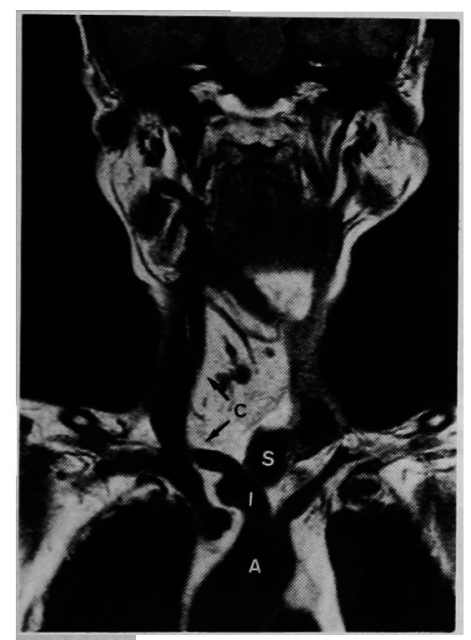

図 5 気管と周囲との関係を示す前額断 MRI（S： 永久気管孔, I：腕頭動脈，A：大動脈弓, C : 総頸動脈)

\section{V. 考 察}

\section{1. 喉頭切除と気管カニューレ}

頭頸部外科とくに悪性腫瘍に対する手術にお いて, 喉頭切除の適応は多い。喉頭癌だけでな く, 下咽頭頸部食道癌や甲状腺癌などの喉頭周 辺臓器癌の気道浸潤に対して治療的に行われる こともあり, 進行口腔癌の広範囲切除では喉頭 には全く浸潤がないにもかかわらず，嚥下性肺

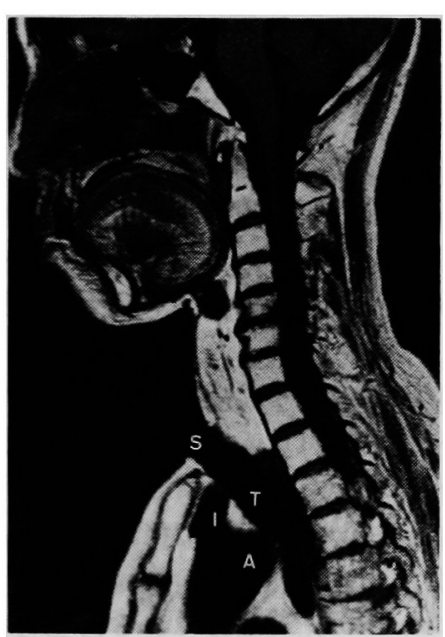

図 6 気管と周囲との関係を示す矢状断 MRI (表示 は図 5 と同じ, T：気管)

炎防止の意味で予防的に全摘せねばならないこ ともある。

喉頭を切除すると気管断端を頸部皮膚に縫合 して永久気管孔を造設する。この気管孔の径は 気道として十分な大きさであるにもかかわら ず, 術後 $7 \sim 10$ 日間については気管カニューレ を装着して気道を確保せねばならない。その理 由は, これらの手術に付随して頸部リンパ節郭 清が行われ，とくに気管周囲リンパ節群すなわ ち気管前リンパ節や気管傍リンパ節の郭清を徹 底させた場合には, 術創にチューブを留置して 陰圧持続吸引を行うのは当然のこととして，加 えて頸部術創とくに永久気管孔周辺へのガーゼ 压迫が必須であり，気管カニューレを装着しな いと,これらのガーゼに埋もれて気道確保が困 難になるからである。

臨床で広く用いられている気管カニューレは 気管切開用に設計されているRが小さいので, 気管孔から分岐部に至る気管の大きな $R$ とは全 く一致せず，不適合のまま使用せざるを得なか ったのが実情である。そこで, 致命的術後合併 症の一つとして腕頭動脈破裂があげられてき た マ-11)にもかかわらず，この不適合について画 像を用いて客観的に示した報告はなく, 抜本的 な解決策も提示されていない。教室では，Rが 大きくほほストレートな全麻挿管チューブを短 く切って用いるなど, 術後管理には万全を期し 
日気食会報，49（6），1998

てきたにもかかわらず，過去10年間に 3 例の腕 頭動脈破裂を経験した。次に最近経験した 1 例 を提示する。

\section{2. 腕頭動脈破裂症例}

症例は下咽頭癌で咽頭喉頭食道全摘, 胃管に よる再建術を施行した。術後数日間は集中治療 室で, 気管孔から挿管チューブを留置し, カフ を使用しつつレスピレーターに接続して呼吸管 理されていたが,一般病棟にもどり従来の気管 カニューレに変更してまもなく腕頭動脈破裂に よる大出血をきたした。おそらく集中治療室て の挿管チューブのカフ圧により気管壁の部分壊 死, 脆弱化が起こり，その気管壁に $R$ 不適合の 気管カニューレ先端部分による物理的刺激が加 わって腕頭動脈破裂を引き起こしたものと考え られた。

\section{3. 気管カニューレのRとの不一致}

臨床で広く使用されている気管カニューレの $R$ が平均 $36 \mathrm{~mm}$ であったのに対して, 永久気管 孔造設後の気管の $R$ の平均值は $293 \mathrm{~mm}$ で, 両 者の不一致が明らかになった。また気管カニュ ーレの多くは50 $\mathrm{mm}$ から $100 \mathrm{~mm}$ の長さで, 成 人用の平均の長さは70 $\mathrm{mm}$ である。この気管力 ニューレを挿入した場合, 図 7 に示すようにそ の先端が気管前壁を圧迫する危険があり，また 多くの症例でその部位の直前に腕頭動脈が存在 することになるので, 物理的損傷による動脈破 裂の危険性が明らかになった。

4. 腕頭動脈破裂予防のための適合カニュー レの設計

気管切開では, 切開されることの多い第 3 気 管輪の高さでは, 前頸部の皮膚から気管までの 距離は富田らの報告6) のように10 mm 前後て あり, 気管カニューレはこの距離をほほ水平に 進入したあと気管切開された気管へ挿入される ように設計されていて，その $R$ は $30 \mathrm{~mm}$ から 41 $\mathrm{mm}$, 平均 $36 \mathrm{~mm}$ である (図 8 )。これに対して 永久気管孔造設後の気管は直接皮膚に縫合され ていて，しかも $R$ は約 $300 \mathrm{~mm}$ と著しく大きい。

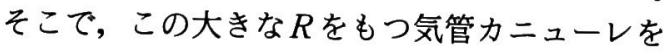
設計試作したものを図 9 に示す。また，これを 永久気管孔に装着した状態を図10に示す。前述 したように気管孔から腕頭動脈までの距離は症 例により（気管切除範囲により）差があるが,

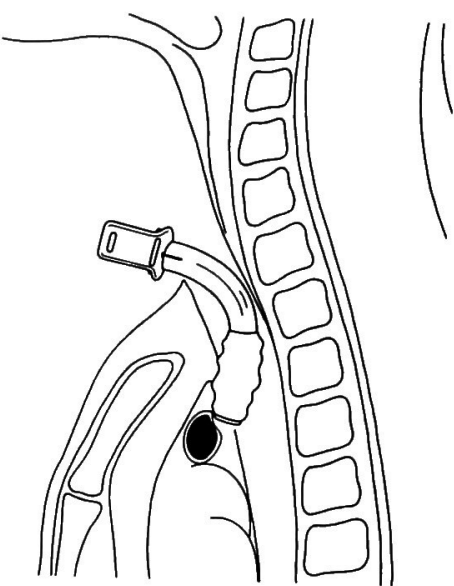

図7気管カニューレによる気管前壁および腕頭動 脈の圧迫

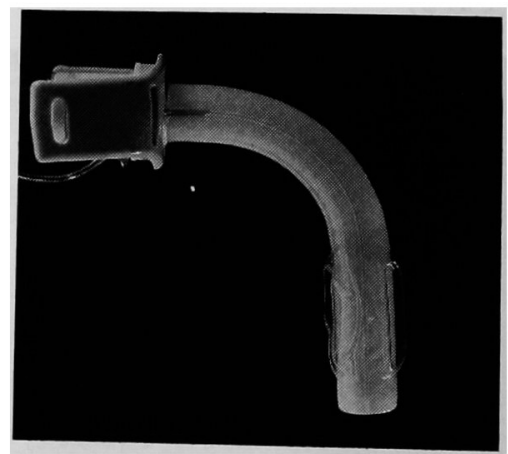

図8 従来の気管カニューレ（Rは40 $\mathrm{mm}$ である $)$

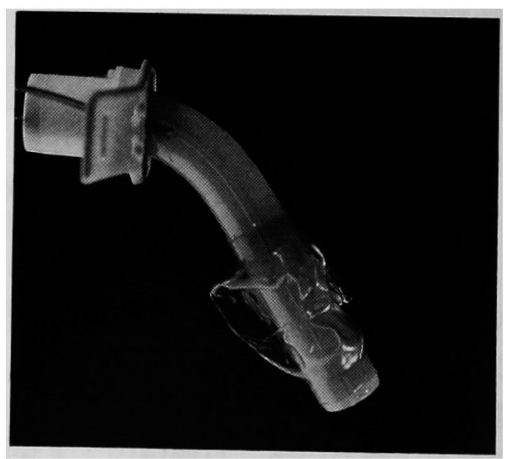

図 9 試作したカニューレ（Rは300 mm である）

この気管カニューレを用いると，その先端は気 管内腔にあって気管壁に接することなく，その 先端で壁を損傷することは考えられないので, 長さは70 mm に一定とした。

喉摘後に適当と思われる気管カニューレとし 


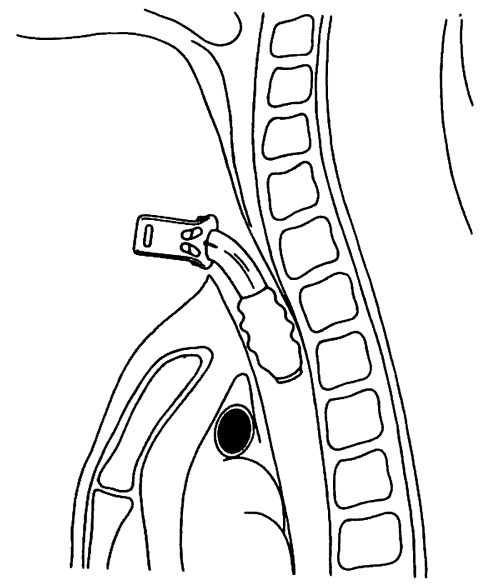

図10 永久気管孔造設後の気管と試作したカニュー レとのマッチング

て現在使用されているものに日本マリンクロッ ト社扱いのシャイリーLGT, トップ社製トップ 気管切開チューブ, 日本シャーウッド扱いのオ ールシリコントラケオストミーチューブなどが ある。これらは通常の気管切開カニューレに比 較すれば $R$ が大きく設計されてはいるものの, 筆者の計測した $R$ とは相当な差があり，より $R$ の大きな（ストレートに近い）形状が望ましい と考える。また, 術直後の呼吸管理ではレスピ レーターに接続して補助呼吸を行うことが多い ので, 低圧カフの使用が必須となる。工作過程 から新設計をすると高額な経費を要するとの理 由で, 現存するものの中から $R$ の変更のみ可能 なものを選択し，設計した。

\section{VI. ま と}

永久気管孔造設後の患者にときとしてみられ る, 致命的合併症である腕頭動脈破裂の成因を 明らかにするために, MRI 矢状断および前額断 画像を用いて気管の $R$ を計測し，周囲組織とく に腕頭動脈との位置関係について調へ, 現在一 般に用いられている気管カニューレの $R$ を計測 して両者を比較検討し, 以下のように結論した。 さらに腕頭動脈破裂の予防を目的として, 適切 な $R$ の気管カニューレを試作した。

1）臨床で広く用いられている成人用気管力 ニューレの $R$ は最小 $30 \mathrm{~mm}$, 最大 $41 \mathrm{~mm}$, 平均 $36 \mathrm{~mm}$ であった。

2 ）永久気管孔造設後の気管の $R$ は最小 160 $\mathrm{mm}$, 最大 $480 \mathrm{~mm}$, 平均 $289 \mathrm{~mm}$ で, 気管カ二 ユーレの $R$ と著しく差があることが明らかにな つた。なおこの計測值について, 気管切断レべ ルによる差, 年齢差, 性差, 頭位による差はい ずれも認められなかった。

3）腕頭動脈は気管前壁に接して斜走し，そ の気管孔からの距離はちょうど気管カニューレ 先端が到達する位置にあることが判明し， $R$ 不 適合カニューレの使用が，気管圧迫壊死さらに 腕頭動脈破裂の成因になるものと判断した。

4) この致命的な合併症を防ぐために, 本研 究で得られた計測値に基づき, 適切な $R$ の気管 カニューレを設計試作した。

稿を終えるにあたり，御指導御校閲をいただいた 京都府立医科大学耳鼻咽喉科学教室村上泰教授に深 謝いたします。

\section{文献}

1) 沼田 勉, 遊座 潤, 片橋立秋 - 他：頸動脈損 傷の予防と対策. JOHNS, $12: 541-545,1996$.

2 ）岡部陽三, 三輪高喜, 渋谷和郎・他 : 気管切開 後の気管腕頭動脈瘦：症例報告と文献的統計. 耳展, 34:461-466, 1991.

3 ) Chew, J.Y., and Cantrell, R.W. : Tracheostomy complications and their management. Arch. Otolaryngol., $96: 538-545,1972$.

4 ) Silen, W., and Spieker, D. : Fatal hemorrhage from the innominate artery after tracheostomy. Ann. Surg., 162:1005-1012, 1965.

5 ) Utley, J.R., Singer, M.M., Roe, B.B., et al. : Definitive management of innominate artery hemorrhage complicating tracheostomy. JAMA, $220: 577-579,1972$.

6 ) 富田 寛, 藤川裕司, 稲名市郎: 気管カニュー レーその基礎的問題と新カニューレの紹介. 日 気食会報, 21 (補)：33-47, 1970.

7 ) Robertson, D.S. : Tracheostomy and open heart surgery. Proc. Roy. Soc. Med., 57 : 855864, 1964.

8 ) Stowe, D.G., Kenan, P.D., and Hudson, W. R. : Complications of tracheostomy. Am. Surg., 36:34-38, 1970.

9 ) 古賀和徳, 岡野龍介, 佐多竹良 - 他 : 気管力二 ューレ長期留置により気管腕頭動脈瘻を合併し た 1 症例. 臨床麻酔, $17: 805-806,1993$.

10）日野原正：気管カニューレの各種. JOHNS, $8: 305-309,1992$.

11）有働幸弘, 中島 格: 気管. 腕頭動脈㿉で出血 死した下咽頭頸部食道癌症例. 日気食会報, 40 : 478-483, 1989. 